\title{
The Welfare State or the Economy? Preferences, Constituencies, and Strategies for Retrenchment
}

\author{
Nathalie Giger ${ }^{1}$ and Moira Nelson ${ }^{2}$
}

\begin{abstract}
The assumption that voters systematically defend the welfare state is challenged by recent research showing that parties are on average not punished and sometimes even rewarded for welfare state retrenchment. We work to understand better the micro-foundations for this finding of non-punishment by exploring individuals' preferences over social policy. In particular, we distinguish general support for redistribution from views that existing levels of government spending strain the economy. As voters value economic stability in addition to equality, they are hypothesized to tolerate or support retrenchment when they feel that there are economic costs at stake. Analyzing a sample of 13 European societies with data from the European Social Survey Round 4, our results show that only welfare state supporters who do not believe that the welfare state hampers the economy punish retrenching governments. This finding helps explain the lack of more widespread electoral punishment following retrenchment, though other results also suggest that retrenchment involves a rather delicate process of juggling the preferences of diverse constituencies.
\end{abstract}

\section{Introduction}

In many countries, parties rolling back social policies have not suffered electoral punishment (Kumlin, 2007a; Armingeon and Giger, 2008; Giger, 2011; Giger and Nelson, 2011), despite strong public support for the welfare state (Gelissen, 2000; Blekesaune, 2007; Jæger, 2009). To explain the lack of electoral punishment, scholars typically draw on the literature on blame avoidance strategies (Weaver, 1986; Pierson, 2001; Hering, 2008) with the implicit assumption that the only way to retrench without losing votes is to hide it. We forward a new argument to explain the nonpunishment finding. In particular, we argue that the perceived economic costs of a large welfare state by some voters counteract their high levels of general support, thereby making them susceptible to tolerating a retrenchment agenda.

Our analysis provides micro-foundations for a common justification of welfare state retrenchment, the state of the economy. As feedback mechanisms legitimate policies over time, politicians in generous welfare states are supposedly constrained in their ability to attack social policies directly. Yet, we believe that, even when blame avoidance strategies are in play, politicians are often hard pressed to articulate carefully and openly why reforms to popular programs are necessary, and that the widespread use of these justification mechanisms largely explains the absence of widespread punishment. For this reason, although the blame avoidance literature depicts politicians as master magicians, drawing eyes away from the truth, we take a slightly different view by arguing that retrenchment can be seen from two anglesrescinding on commitments to social justice or restoring economic competitiveness-and that politicians will intentionally focus attention to the latter because the view that cutbacks help the economy are widespread and people care about the economy.

As this line of argumentation suggests, we have to disentangle general beliefs about the welfare state from attitudes regarding its perceived costs. Data show that, while general support for redistribution remains strong, large shares of pro-welfare voters also believe that generous social policies hamper economic

\footnotetext{
${ }^{1}$ Department of Political Science, University of Zürich, Affolternstr. 56, 8050 Zürich, Switzerland and ${ }^{2}$ Department of Political Science, Lund University, Box 52, SE-22100 Lund, Sweden.

Corresponding author. Email: moira.nelson@svet.lu.se; nathalie.giger@mzes.uni-mannheim.de
} 
competitiveness. Further analysis demonstrates that parties' constituencies vary systematically in their beliefs over the welfare state and its economic costs, and our results show that only welfare state supporters who do not believe that the welfare state hampers the economy punish retrenching governments. The implications of this finding for the politics and electoral consequences of welfare state retrenchment are explored.

The article proceeds as follows. The next section outlines the theoretical framework and explores the apparent contradiction that arises from high general support for the welfare state and the absence of electoral costs for retrenching governments. Second, partisan hypotheses are derived for retrenchment activity and electoral punishment. After reviewing the methodology, these hypotheses are then tested and the results discussed. The final section concludes.

\section{Distinguishing Two Dimensions of Welfare State Preferences: General Support for Social Policy and the Perceived Costs of Social Policy}

Belief systems in general and attitudes toward the welfare state in particular are known to be complex and comprise more than a single dimension (Converse, 1964; Zaller, 1992). Even for the subfield of welfare state attitudes, one can separate several layers, objectives, and aspects [for a summary see Kumlin (2007b)]. Further, socio-psychological work teaches us that not all attitudes have the same relevance for political behavior, as certain aspects of our belief systems are more easily accessible than others (Fazio, 1986; Bartels, 2008), and citizens can hold seemingly conflicted or ambiguous attitudes toward certain political topics (Kinder, 1994; Krosnick, 1990). In this way, assuming unyielding political support for all components of the welfare state from evidence of high general support for the idea of redistribution seems hasty and potentially erroneous. ${ }^{1}$ Hence, we propose to consider the interconnectivity between general support and views regarding the economic costs of social spending to derive a more nuanced picture of how citizens value the welfare state and where they potentially disagree with the current government policies [for a similar argument about the need for more disaggregation see Jakobsen (2010)].

Despite these insights into the complex nature of public opinion, the mainstream welfare state literature tends to focus almost exclusively on generalized support for the welfare state in examining the role of public opinion on welfare state reform. Studies based on such survey data convincingly demonstrate that a majority of individuals support the principle of redistribution (Gelissen, 2000; Blekesaune, 2007; Jæger, 2009). ${ }^{2}$ In this way, on a general level of social policy attitudes, we indeed find overwhelming support for the welfare state. Yet, analyses of welfare state reform often proceed on the assumption that only generalized support for the welfare state matters to voters and, by extension, the role of voters in structuring retrenchment activity and subsequent electoral fallout.

Without contesting the finding of high generalized support, we aim to incorporate the insights about the complexity of belief systems more firmly into the literature on welfare state reform. While the range of additional dimensions to belief systems is likely large, we focus in the remainder of this study on the role of beliefs about the economic costs of the welfare state. There are many reasons to expect that the state of the economy influences social policy preferences and therefore politics of welfare reform. As case in point, despite high levels of support for the welfare state per se, there is also evidence that citizens value not only social policies but also a sound fiscal policy and a thriving economy (Nannestad and Paldam, 1994; Boeri, Börsch-Supan and Tabellini, 2001). Governments are also judged heavily on the state of the economy (Kiewiet, 1984; Lewis-Beck, 1986, 1988; Powell and Whitten, 1993), which makes politicians attune to voters' perceptions of government performance on economic matters.

Demand for a strong economy should also hold implications for how voters evaluate the economic sustainability of the welfare state. The welfare state is often attacked for weakening the economy (Larsen and Andersen, 2009), and this view has gained momentum in recent decades because of the rise of the Neoliberal orthodoxy. Although heightened competition, a tighter macroeconomic environment, and demographic change certainly challenge the sustainability of traditional welfare state arrangements, neo-liberal rhetoric often claims that all types of government spending impede economic competitiveness, even as research shows that some social policies are actually supportive of the economy (Bradley and Stephens, 2007). Additionally, while right-leaning parties have long used neo-liberal and other ideas to argue that social spending threatens economic competitiveness, governments of all shades have leaned on the argument of economic hardship in justifying more stringent social agendas.

Drawing on the aforementioned discussion, individuals may be thought to hold at least two dimensions of attitudes toward the welfare state: general preferences 
over their preferred level of social justice and views on the extent to which budgetary commitments to the welfare state hold negative economic ramifications. To some extent, one might expect strong affinities between these two dimensions. As individuals seek to reduce cognitive dissonance (Festinger, 1957), they likely modify their views on social justice to accommodate beliefs about the economy.

At the same time, completely eliminating cognitive dissonance from one's belief system is unlikely because the world is complex, and views toward its appropriate structure are contingent on a host of factors. As a result, an individual may hold preferences toward the welfare state, which appear at first sight internally inconsistent, in the sense that the achievement of one goal impedes the realization of another but which, in fact, reflects a nuanced view of a highly complex and interrelated world. For instance, an individual can support the general picture of social assistance to the needy and at the same time agree to tighter eligibility rules for social assistance to avoid abuse or productivity losses due to reduction in labor supply. In this way, divergent answers do not necessarily indicate ambivalence but merely reflect different types of welfare attitudes and the interconnectivity of attitudes. In conclusion, we posit that all combinations of the two dimensions mentioned previously are theoretically reasonable and empirically observable. For example, we anticipate people who believe in social justice and do not see economic trade-offs in enacting related policies, as well as citizens who support the general principle of social redistribution but question the economic sustainability of the welfare state. To analyze the mutual importance of general beliefs over redistribution and beliefs about the economic costs to social spending, we derive four descriptive groups, which are expressed below in Table 1.

The first row contains those who believe that the welfare state incurs economic costs. Individuals who believe that social spending hampers the economy but nevertheless want to redistribute income are labeled 'conditional believers' because they favor redistribution, which they nevertheless see as harmful to the economy. Those who believe cuts would help but do not want to redistribute are labeled 'economic opposers', as their views align closely with the perspective that market mechanisms alone are preferable.

Turning to the groups that disagree with the idea that the welfare state is economically unsustainable, we find two divergent groups. We label the first group 'unconditional believers' because they want a welfare state and are not persuaded that this goal carries economic burdens. Finally, we label those against the welfare state but not because of its economic costliness 'unconditional opposers', as their preference for low government spending does not follow an economic imperative and is therefore of a more fundamental nature.

Mapping social policy attitudes on these two dimensions provides leverage in grasping how parties are able to retrench despite high popular support for redistribution. People in our category 'conditional believers', for example, are exactly those citizens 'wrongly' classified by the current literature. If we only considered general welfare state beliefs, we would see them all as fully supportive of the welfare state and hence willing to punish retrenching governments. Broadening our perspective to take a more encompassing view of welfare state attitudes, however, reveals that these people share concerns about the costs of social policy, which arguably temper their proclivity toward electoral punishment, particularly if the governing parties manage to justify retrenchment convincingly with arguments about its economic pay-offs. In this way, holding a pro-market stance does not preclude support for the general principle of social equality, although these general beliefs are probably less relevant for their voting behavior. ${ }^{3}$ Therefore, while social policy researchers tend to focus exclusively on the high levels of general support, the assumption that this support translates into cutbacks being unpopular and therefore electoral backlash is too hasty. In the space that follows, we explore more in depth the link between general beliefs over redistribution and the perceived costs to social spending to understand how appeals to the economic costs of the welfare state may facilitate retrenchment for different party families.

Table 1 Preferences over the welfare state: general beliefs versus economic costs

\section{General welfare state support}

High

\begin{tabular}{ll}
\hline Perceived costs of welfare state \\
High & Conditional believers \\
Low & Unconditional believers
\end{tabular}

Low

Economic opposers

Unconditional opposers 


\section{Puzzles for Welfare State Research: Implications of Complex Belief Systems for Theories of Retrenchment and Electoral Punishment}

Allowing for multiple belief dimensions opens up the possibility that the group of inconsolable punishers is smaller than previously expected. Only some welfare state supporters, our subset of 'unconditional believers', are disinclined to accept arguments that retrenchment is necessary to sustain economic competitiveness over the long term. Of course, if individuals indeed seek high levels of cognitive consistency, the group of 'conditional believers', i.e. welfare state supporters who nevertheless believe there to be economic costs to social spending, will be small. On the other hand, if this group is not small, we posit that this holds major implications for our understanding of both government retrenchment activity and the electoral costs of retrenchment. Let us now elaborate on our expectations in more detail.

As it stands, the finding of high general support for the welfare state leads to the common inference that all mainstream parties rely on 'anti-cutback' constituencies. Drawing on the framework in Table 1, we challenge this conclusion and contend that the crucial question is rather whether all party electorates reveal the same share of 'conditional' and 'unconditional' believers, respectively, with the intuition that only the latter are clearly anti-retrenchment. The historic commitment of left (Stephens, 1979; Korpi, 1983) and religious parties (Huber, Ragin and Stephens, 1995; van Kersbergen, 1995; van Kersbergen and Hemerijck, 2004) to the welfare state should help them garner support among unconditional believers. Moreover, as the literature has shown that right parties retrench more often than left parties (Korpi and Palme, 2003; Allan and Scruggs, 2004), we find good reason to expect that parties' constituencies continue to vary systematically today. Specifically, we hypothesize that clearly left-leaning parties (left socialist and socialist) have the highest proportion of unconditional believers, followed by religious, and then more right-leaning parties, including conservative and liberal parties (which we do not distinguish from each other). In addition, we hypothesize the reverse ordering for the proportion of voters falling into the conditional and unconditional opposers category, respectively. ${ }^{4}$

Our theoretical framework renders possible one more group, that of conditional believers: those that want the welfare state but agree that cutting it back would improve the economy. To understand the broader implications of conditional believers, more information about the hierarchy of these attitudes would be necessary: do positions over general support override those about the economic costs or vice versa? Do preferences apply to particular policy domains or groups of individuals?

Given the multitude of reasons why individuals may hold conflicted preferences, we hypothesize that all parties have relatively high shares of such voters but for different reasons. For instance, people with a leftist ideology should find it hard to deny the general principle of social justice even though some of them might buy into neo-liberal arguments about the costliness of government spending. However, they should only express their concerns on the more concrete aspects of welfare state attitudes such as questions related to economic feasibility of high standards of welfare state generosity. A different reasoning is expected for people with a more right-wing ideology. While most of them should agree without hesitation that less state spending is good for the economy, they might be inclined to support the general principle of welfare spending because the welfare state has become the status quo.

Empirical support for our hypotheses speaks to parties' incentives to propose a retrenchment agenda, and these issues are taken up further in the 'Results' section. Another straightforward implication of our framework, however, involves expectations regarding the electoral backlash associated with retrenchment. Again building on Table 1, we theorize that only 'unconditional believers' systematically withdraw support for retrenching governments. Helping the economy is not an excuse to do away with the welfare state according to these voters, which makes them unforgiving of parties that roll back social benefits.

While also supportive of the welfare state, conditional believers are, on the other hand, susceptible to lines of argumentation that retrenchment improves the state of the economy. If parties fail to justify retrenchment, these voters may indeed punish them by voting for another party. However, we expect this to be the exception rather than the rule. Parties are incredibly strategic actors and can be expected to highlight the economic repercussions of reforms or focus electoral campaigns on the economy if doing so holds the potential to win over reluctant voters. As such, we expect there to be no systematic punishment by conditional believers as a result. Economic and unconditional opposers are not expected to punish and may even reward retrenching governments.

To conclude, our argument nuances the widespread assumption that those who support the welfare state on a 
general level (i.e. both conditional and unconditional believers) punish retrenching governments. In doing so, affirmative results hold the potential to explain the lack of large-scale electoral punishment.

\section{Data and Method}

The data come from the European Social Survey's Round 4 (2008). Specifically, we used the following two questions to set up our analysis. First, the general welfare state beliefs question has the following form: the government should take measures to reduce differences in income levels; the five answer categories range from 'disagree strongly' to 'agree strongly'. We believe that this question taps into a general dimension of welfare state attitudes and has also often been used to operationalize welfare state beliefs.

Second, to operationalize the dimension of perceived costs of social security, we use the following statement: social benefits/services place too great strains on the economy. The five response categories again run from 'disagree strongly' to 'agree strongly'. The question we use is phrased in a broad way. We interpret individuals' response to this question as a reflection of their own individual position, as well as their views of the rest of the society. The way in which individuals weigh their own and the common good depends on the individual.

These two questions are used to construct the groups indicated in Table 1. In particular, we combined the categories 'agree strongly' and 'agree', as well as 'disagree strongly' and 'disagree', of each the question. ${ }^{5}$ Both questions include a neutral category, a group that does not lend itself to classification in any one of our four groups.

In a first step, for the empirical analyses of the implications of our framework, the group variables from Table 1 become the focus of analysis. Focal independent variables are the identifiers for the party families. We distinguish between left socialist parties, socialist, and religious parties on the left side of the spectrum and conservative and liberal parties on the right. The categorization follows Armingeon et al. (2008).

In a second step, vote for an incumbent party during the last election serves as the dependent variable, with the group variables from Table 1 being the independent variables. ${ }^{6}$ Further, we control for a number of factors known to influence the vote choice in favor of an incumbent party, such as the perception of the state of the economy, age, and gender (Lewis-Beck and Stegmaier, 2007; Giger, 2011). At the macro level, we include a control for the ideological leaning of the government, as left-wing governments could be differently punished than right-wing governments (Giger and
Nelson, 2011). This variable captures the share of left parties in the cabinet and is taken from Armingeon et al. (2008).

Our models include an identifier for the presence of cutbacks coded by the authors. The data about welfare state reforms come from the ISSA Database on international social security. ${ }^{7}$ According to the theoretical interest of this study, only major reforms that had a clear focus on benefit reduction have been classified as cutbacks. Further, only reforms in the key schemes of social security (unemployment, health, and pensions) are taken into account.

We reduce the sample to western European, which has industrialized countries with a developed system of social security, as only with this sample the social and economic background is sufficiently similar. In detail, we include the following countries in our analyses: Belgium, Denmark, Finland, France, Germany, Great Britain, Ireland, The Netherlands, Norway, Portugal, Spain, Sweden, and Switzerland.

Multilevel regressions are the methods of choice to take the clustering of the data by countries into account. This strategy also bears the advantage that the context variance component captures between-country or between-regime differences in the size of our four groups, and we do not need to control specifically for such contextual factors anymore, an endeavor problematic anyway because of the limited amount of country contexts (13). Our binary dependent variables ask for a specific link function (Long, 1997).

\section{Empirical Findings}

\section{Two dimensions of welfare state preferences}

To begin, we show responses to the two main questions under inspection to assess the degree of cognitive consistency. If asked about the general principle that the government should reduce the income differences between rich and poor, a large majority supports this claim (see Figure 1). Also, when assessing support by party families, we do not find huge differences. While liberal and conservative party constituencies are slightly less likely to agree with the question (57.8 and 51.8 compared with an average of $73.7 \%),{ }^{8}$ the picture of a high general support portrayed in the literature is confirmed here.

However, we believe that this graph is not showing the whole picture, as it only looks at a general level of welfare state attitudes. Our earlier discussion proposed another dimension, which considers the perceived costs of the welfare state. To this end, we draw on a question about the economic trade-offs to a large welfare state. 


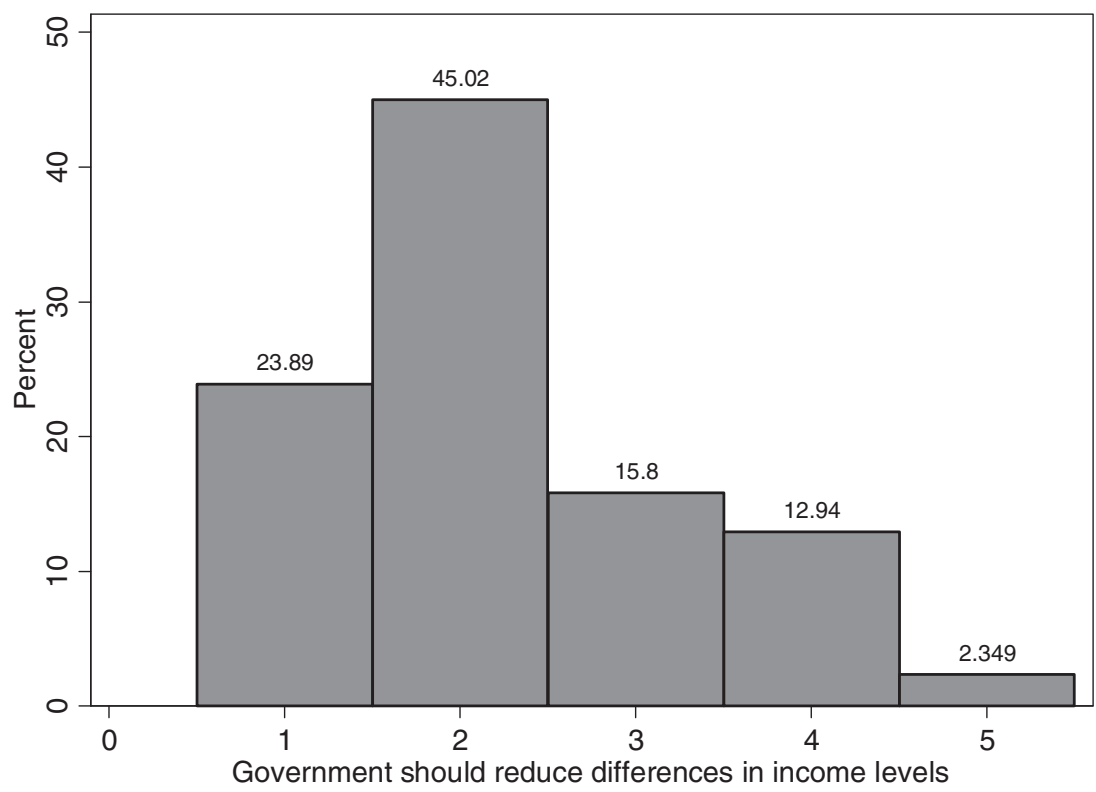

Figure 1 Support for the general principle of redistribution. Source: ESS 2008 (1-agree strongly, 5-disagree strongly).

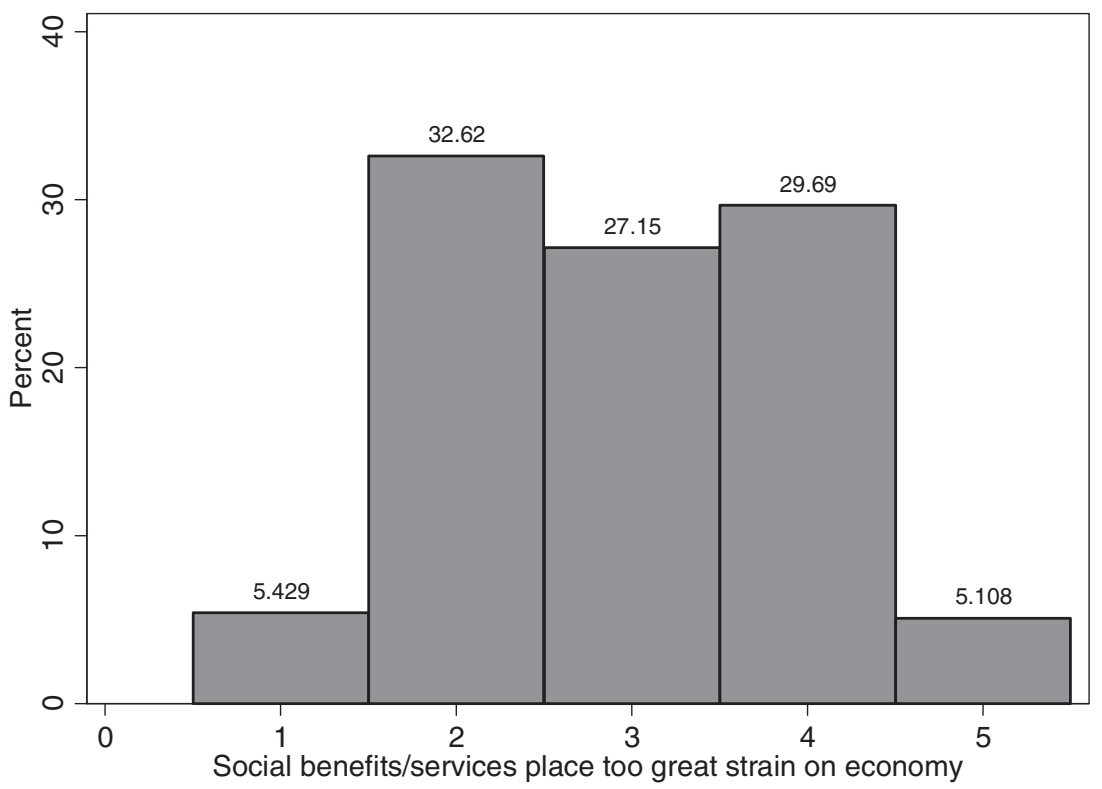

Figure 2 Answers to the economic costs question: whether cuts in government spending are a good thing for the economy. Source: ESS 2008 (1-agree strongly, 5-disagree strongly).

Figure 2 plots the answers to the question whether social benefits and services place too heavy constraints on the economy.

In Figure 2, it becomes visible that concerns about the economic costs of social security are widespread.
On average, $38 \%$ believe such costs exist with only $\sim 35 \%$ denying the existence of a trade-off between economic performance and high standards of social welfare. While partisan differences are apparent, a large number of supporters from each party family think that 
social benefits place heavy constraints on the economy; among pro-welfare parties, $19.5 \%$ of left socialist, $32.3 \%$ of socialist, and $41.9 \%$ of religious supporters at least agree, whereas, on the other side of the spectrum, $45.5 \%$ of conservative and $41.4 \%$ of liberal supporters do so.

Considering Figures 1 and 2 together, it becomes obvious that there must be a substantive portion of people with apparently inconsistent preferences insofar as they agree with the general principle of the welfare state as well as the idea that the welfare state places excessive strain on the economy. To gain leverage on the size and political representation of this group, we calculate the size of the four groups identified in Table 1 and examine how parties differ in their reliance on each one. Table 2 gives a first impression of the size of these groups overall (see the last row) and by party family.

\section{Implications for partisan strategies to retrench}

Starting with the last row of Table 2, we see that the largest category after 'Other' in our schema includes people with cognitive inconsistencies, i.e. conditional believers. Approximately $26 \%$ of all citizens line up in this category. The impressively high numbers of people in this category make it clear that we cannot just qualify them as a small minority who did not understand the survey correctly. We believe that this pattern is therefore better interpreted as showing a substantively interesting pattern, which is consistent with research on political attitudes: citizens agree with the general principle of reducing income differences but are clearly of the opinion that the welfare state impedes economic competitiveness. A result of our schema is that the group of unwavering welfare state supporters, unconditional believers, no longer constitutes a clear majority of the electorate. On average, we find $24.8 \%$ of the sample in this category. Even fewer people are unconditional opposers who are against the (welfare) state but not apparently because they perceive it to incur high costs (6.4\%). The group of economic opposers $(4.9 \%)$, people whose lack of support for the welfare state can be linked to the belief that social spending hurts the economy, is also small.

Turning to the more detailed results, left socialist, socialist, and religious parties can be seen to draw, in that order, more unconditional believers than more right-leaning parties. In accordance with our expectations, all party constituencies have rather large shares of conditional believers. The highest share of economic opposers is found in the conservative party family $(8 \%)$, as expected, although the remaining parties do not lag far behind. The group of unconditional opposers is also highest among conservative parties (13.6\%), followed by the liberals, and then religious and other left parties. ${ }^{9}$

Based on these results, we can begin to consider how parties' constituencies shape the viability of a retrenchment agenda. First, we posit that parties relying on many unconditional believers do not consider a retrenchment platform. Admittedly, we have not considered the full range of alternative dimensions to voters' belief systems; as beliefs about the economic costliness of social policy temper general support, there may be other factors that do so as well. Nevertheless, the economic sustainability frame is dominant, and we therefore proceed on the assumption that voters who disagree that there are economic costs to high social spending hold unsupportive views of retrenching governments. Left socialist and socialist parties should be particularly opposed to retrenchment given the size of this group within their constituencies. Our schema therefore suggests a vote-seeking explanation for why left-leaning parties retrench less: left-leaning parties refrain because their supporters cannot be won over by savvy political argumentation. At the same time, the finding that all

Table 2 Distribution of constituencies' preferences

\begin{tabular}{lccccc} 
Party Families & $\begin{array}{l}\text { Unconditional } \\
\text { believers }\end{array}$ & $\begin{array}{l}\text { Conditional } \\
\text { believers }\end{array}$ & $\begin{array}{l}\text { Economic } \\
\text { opposers }\end{array}$ & $\begin{array}{l}\text { Unconditional } \\
\text { opposers }\end{array}$ & Other \\
\hline Left socialist & 46.0 & 18.2 & 3.0 & 2.1 & 30.7 \\
Socialist & 32.5 & 25.5 & 4.7 & 3.7 & 33.6 \\
Religious & 23.7 & 22.6 & 5.5 & 6.9 & 41.3 \\
Conservative & 14.1 & 21.3 & 8.0 & 13.6 & 42.9 \\
Liberal & 19.9 & 27.8 & 7.6 & 9.2 & 35.5 \\
Overall & 24.8 & 26.0 & 4.9 & 6.4 & 35.2 \\
Number of observations & 6,218 & 6,517 & 1,293 & 1,695 & 9,311 \\
\hline
\end{tabular}

Note: Entries are percentages, the row 'Total' reports averages weighted by countries. 
parties draw on unconditional believers to some extent explains why parties of diverse ideological leanings avoid attacking social justice directly. Any party clearly prioritizing the economy over goals of social justice opens itself up to criticism by the opposition or the media.

The particular make up of a political party's constituency in terms of these four groups also provides information on the diversity of interests, which parties must consider when drawing up reform proposals. Our finding of highly diverse party constituencies potentially goes some way in explaining the status quo bias of current welfare state politics. If a party has for instance both high shares of unconditional believers and economic opposers, it faces the challenge of proposing policy reforms that can, on the face of things, only disappoint part of their constituency. Such parties may enact blame avoidance strategies more often. At the same, managing diversity through blame avoidance may be a self-defeating strategy over the long run if it blurs party identity and issue ownership. As such, parties may consciously accept defection from unconditional believers if doing so allows them to take stronger positions on issues of economic competitiveness and thereby appeal to more centrist voters and parties [for a related argument see Schumacher (2012)].

The fact that large shares of the population at least partially buy into arguments that there are economic costs to the welfare state also provides microfoundations for why justifying cutbacks by appealing to economic arguments occurs so often [see GreenPedersen (2002)]. If parties are successful in making economic concerns salient, these likely override general welfare state beliefs. More broadly, our findings highlight the importance of framing in social policy reforms [see Slothuus (2007)].

\section{Implications for electoral punishment}

Our argument also has potentially important implications for our understanding of the electoral costs associated with social policy cutbacks. While the current literature proceeds rather quickly from notions of high support for the welfare state to expectations about electoral consequences, our framework allows us to formulate more nuanced expectations about possible effects of cutbacks for incumbent popularity. Specifically, we expect only one group to be unforgiving of social policy cutbacks, unconditional believers. While supportive of the welfare state on a general level, conditional believers nevertheless perceive economic liabilities to a large welfare state and are less likely to punish incumbents for retrenchment in social policy as a result. The empirical evidence provided in Table 2 provides a first snapshot in favor of our expectation: only about half of welfare state believers do not consider there to be economic costs and are thus expected to dislike retrenchment per se. In a more thorough test of the implications of our framework, we assess the support for retrenching governments of each group identified in Table 1.

Table 3 provides the corresponding results. Model 1 reports the results for the full sample, i.e. all our 13 countries. While unconditional believers are not generally less supportive of the incumbents, we find that the variance in the strength of the effect is large, visible in the large random component for the identifier for unconditional believers. In other words, there are instances where unconditional believers are systematically voting less for incumbents, whereas in other instances, there is no discernible difference between conditional and unconditional believers. This finding is in accordance with our expectation that a difference between the two groups should only be present after a government retrenched the welfare state. Therefore, in a second step, we split the sample and look separately at countries where cutbacks took place during the last term of the incumbents versus countries without significant cutbacks (Models 2 and 3, respectively). We find that unconditional believers are systematically more likely to vote against incumbent governments when they retrenched but not when they did not do so. These findings indicate on the one hand that indeed incumbents can suffer from retrenching social policy but are also in accordance with recent literature, which shows that the effects are not as widespread and not as harmful as previously expected (Armingeon and Giger, 2008; Giger, 2011; Giger and Nelson, 2011). In sum, the finding that many welfare state believers do not systematically punish the government for retrenchment is an important step forward into understanding the dynamics of retrenchment activities.

To conclude, this study shows that the picture of overwhelming popular support for the welfare state is misleading, as citizens have complex attitudes toward the welfare state, and only a minority supports redistribution unconditionally. In particular, we draw attention to concerns about the state of the economy as signifying a dimension of belief systems, which potentially overrides general beliefs about social justice.

\section{Conclusions}

Recent studies problematize the assumption that voters always punish retrenching parties by showing that, on the aggregate, some parties gain votes or 'claim credit' 
Table 3 Logistic multilevel regressions

\begin{tabular}{|c|c|c|c|c|c|c|}
\hline \multirow[t]{2}{*}{$\begin{array}{l}\text { Dependent variable: } \\
\text { incumbent vote }\end{array}$} & \multicolumn{2}{|c|}{$\begin{array}{c}\text { Model } 1 \\
\text { Full sample }\end{array}$} & \multicolumn{2}{|c|}{$\begin{array}{c}\text { Model } 2 \\
\text { Countries with cutback }\end{array}$} & \multicolumn{2}{|c|}{$\begin{array}{c}\text { Model } 3 \\
\text { Countries without cutback }\end{array}$} \\
\hline & Coeff. & St. Err. & Coeff. & St. Err. & Coeff. & St. Err. \\
\hline \multicolumn{7}{|l|}{ Fixed effects } \\
\hline Constant & -0.68 & $0.28^{* * *}$ & -0.98 & $0.32^{* * *}$ & -0.65 & $0.22^{* * *}$ \\
\hline Unconditional believers & -0.26 & 0.23 & -0.17 & $0.07^{\star * *}$ & -0.08 & 0.08 \\
\hline \multicolumn{7}{|c|}{ Conditional believers (reference category) } \\
\hline Economic opposers & -0.16 & $0.07^{\star *}$ & -0.09 & 0.10 & -0.19 & $0.11^{\star}$ \\
\hline Unconditional opposers & 0.13 & 0.08 & 0.28 & $0.11^{\star *}$ & 0.15 & 0.13 \\
\hline Others & -0.10 & $0.05^{\star *}$ & -0.01 & 0.06 & -0.22 & $0.07^{\star * *}$ \\
\hline Age & 0.01 & $0.00^{* * *}$ & 0.01 & $0.00^{* * *}$ & 0.00 & 0.00 \\
\hline Gender & 0.08 & $0.04^{\star *}$ & 0.10 & $0.05^{\star *}$ & 0.06 & 0.05 \\
\hline Perceived economic conditions & 0.07 & $0.01^{\star * *}$ & 0.07 & $0.01^{\star * *}$ & 0.07 & $0.01^{* * *}$ \\
\hline Left-wing government & -0.00 & 0.00 & 0.00 & 0.00 & 0.01 & 0.00 \\
\hline \multicolumn{7}{|l|}{ Random effects } \\
\hline Individual level variance & 1.00 & 0.00 & 1.00 & 0.00 & 1.00 & 0.00 \\
\hline Context level variance & 0.30 & 0.12 & 0.41 & 0.21 & 0.05 & 0.04 \\
\hline Unconditional believers variance & 0.62 & 0.26 & & & & \\
\hline Covariance & -0.00 & 0.18 & & & & \\
\hline Number of cases (countries) & \multicolumn{2}{|c|}{$13,482(13)$} & \multicolumn{2}{|c|}{$7,941(8)$} & \multicolumn{2}{|c|}{$5,540(5)$} \\
\hline Log likelihood & \multicolumn{2}{|c|}{$-8,751.1$} & \multicolumn{2}{|c|}{$-5,132.2$} & \multicolumn{2}{|c|}{$-3,738.6$} \\
\hline
\end{tabular}

Note: ${ }^{*} P<0.1,{ }^{* *} P<0.05,{ }^{* *} P<0.01$.

for retrenching (Giger and Nelson, 2011), and most parties do not lose votes at all. Although one could interpret these results as showing that parties are skillful masters of blame avoidance, we believe that another side to this story exists, namely, that voters do not censure governments for welfare state rollbacks as strongly as previously thought. To summarize the main thrust of our analysis, we have argued that the perceived economic strain of social spending tempers generalized support for redistribution and makes many voters relatively more tolerant of a retrenchment agenda.

In our framework, individuals hold both general views toward redistribution and at least somewhat orthogonal views about the strain of the welfare state on the economy. Indeed, our results show that, although a vast majority of those sampled generally agree that a more equal society is a normative priority, many reveal concerns that there are economic costs at stake. All parties draw heavily from this group of voters. The fact that many people perceive trade-offs to high government spending suggests that how the government pursues certain goals is of critical importance. More than the smoke and mirrors assumed in the blame avoidance literature, our results suggest that governments use an economic frame to justify retrenchment and avoid losing votes.

We would like to end with a few caveats and suggestions for future research. First, future research could consider additional frames governments use to build legitimacy for their preferred reforms. Also, so far, our framework allows us to distinguish between two dimensions of welfare state attitudes. Arguably, this still might not do justice to the complexity of welfare beliefs, as attitudes toward social welfare are even more multifaceted than what has been assumed here. For example, our questions about redistribution might only be partially capturing general beliefs about social welfare, and other concerns such as the security dimension of social welfare [see Petersen, (1995)] remain untouched.

Our analysis also suggests that the blame avoidance literature does not give due attention to perceptions about the economic sustainability of the welfare state. The link between government spending and poor economic performance is in no way straightforward, and we are not presuming that there is a necessary link. However, the rise of the neo-liberal orthodoxy and weak economic performance in the context of strong welfare states arguably holds implications for public opinion. The environment of permanent fiscal austerity and severe economic conditions together with the demographic challenges might make people more responsive to claims of endangered economic sustainability of the current system of social welfare. At the same time, just as generalized support for the welfare state does not lead to unconditional defense of existing policies, a more austere economic climate does not automatically translate into 
beliefs that all forms of social spending are inefficient and need to be cut back. Particularly, during this economic crisis as many European governments attempt to convince their voters that painful reforms are necessary, we are reminded that public opinion remains highly contextualized. Actually, a weak economic context boosts general support for redistribution (Blekesaune 2007), underscoring again ambiguities in our understanding about how general beliefs and those over the economic costs to the welfare state are reconciled. In this way, while our results uphold the expectation that the economic frame is a viable strategy for convincing conditional believers to tolerate a retrenchment agenda on average, further research is necessary to understand when parties adopt such a frame and the consequences of doing so.

\section{Notes}

1 This critique becomes particularly relevant when predictions such as high electoral risks are derived from these survey data.

2 This question taps more into redistribution understood as an exchange from the rich to the poor (social justice) rather than over the life cycle (which would suggest an insurance function) (Barr, 2001). However, as there is sufficient overlap in both functions of social policy, we believe that we are sufficiently capturing general support across diverse welfare states.

3 Giger (2011) provides more information under which circumstances welfare state attitudes are better or worse predictors of electoral behavior. Kumlin (2007b) and the literature on political attitudes in general show that general beliefs have least relevance for actual behavior, whereas more concrete policy-related attitudes have a higher chance to translate into behavior.

4 The conditionality of opposers' anti-welfare stance is not expected to depend on partisan ideology and therefore not considered further within this article.

5 Both questions have a neutral category ('neither agree nor disagree'), which has been coded into the category 'other'.

6 The Netherlands constitutes a special case in this respect as a caretaker cabinet (Balkenende III, CDA, and VVD) faced election in 2006, which was only in power for 135 days before election day. Given the large overlap of parties in power compared with
Balkenende II (CDA, VVD, and D66), we coded the Balkenende II cabinet as in power from 27 May 2003 onward.

7 This database offers summaries of important reforms in social protection and covers all countries in the sample of the study (www.issa.int). Additionally, we cross-checked our coding against two recent publications (Palier, 2010; Clasen and Clegg, 2011).

8 Results not shown here but available from the authors on request.

9 In several countries, there are $\mathrm{N}<30$ respondents in this particular group.

\section{Acknowledgements}

The names are listed in the alphabetical order both authors contributed equally. This paper has been presented at the Dreiländertagung of the Swiss, the Austrian, and the German Political Science Association in Basel, 2010, and during the SASE Annual Conference in Madrid, 2011. This article profited greatly from the comments of the workshop participants. The usual disclaimers apply.

\section{References}

Allan, J. P. and Lyle, A. S. (2004). Political Partisanship and Welfare State Reform in Advanced Industrial Societies. American Journal of Political Science, 48, 496-512.

Armingeon, K. and Giger, N. (2008). Conditional punishment: a comparative analysis of the electoral consequences of welfare state retrenchment in OECD-nations, 1980-2003. West European Politics, 31, 558-580.

Armingeon, K. et al. (2008). Comparative Political Data Set 1960-2006. Berne: Institute of Political Science, University of Berne.

Barr, N. (2001). The Welfare State as a Piggy Bank. Oxford: Oxford University Press.

Bartels, L. (2008). The Opinion-Policy Disconnect: CrossNational Spending Preferences and Democratic Representation. Unpublished manuscript, Princeton University.

Blekesaune, M. (2007). Economic conditions and public attitudes to welfare policies. European Sociological Review, 23, 393-403.

Boeri, T., Börsch-Supan, A. and Tabellini, G. (2001). Would you like to shrink the welfare state? A survey of European citizens. Economic Policy, 16, 9-50. 
Bradley, D. H. and Stephens, J. D. (2007). Employment performance in OECD countries. Comparative Political Studies, 40, 1486-1510.

Clasen, J. and Clegg, D. (2011). Regulating the Risk of Unemployment: National Adaptations to Post-industrial Labour Markets in Europe. Oxford: Oxford University Press.

Converse, P. (1964). The nature of belief systems. In Apter, D. (Ed.), Ideology and Discontent. New York: Wiley, pp. 206-261.

Fazio, R. H. (1986). How do attitudes guide behavior? In Sorrentino, M. R. and Higgins, E. T. (Eds.), Handbook of Motivation and Cognition: The Interpersonal Context. New York: Guilford Press, pp. 204-243.

Festinger, L. (1957). A Theory of Cognitive Dissonance. Evanston, IL: Peterson and Company, Stanford University Press.

Gelissen, J. (2000). Popular support for institutionalised solidarity: a comparison between European welfare states. International Journal of Social Welfare, 9, 285-300.

Giger, N. (2011). The Risk of Social Policy? The Electoral Consequences of Welfare State Retrenchment and Social Policy Performance in OECD Countries. London: Routledge.

Giger, N. and Nelson, M. (2011). The electoral consequences of welfare state retrenchment: blame avoidance or credit claiming in the era of permanent austerity? European Journal of Political Research, 50, $1-23$.

Green-Pedersen, C. (2002). The Politics of Justification: Party Competition and Welfare-State Retrenchment in Denmark and the Netherlands from 1982 to 1998. Amsterdam: Amsterdam University Press.

Hering, M. (2008). Welfare state restructuring without grand coalitions: the role of informal cooperation in blame avoidance. German Politics, 17, 165-183.

Huber, E., Ragin, C. and Stephens, J. D. (1995). Social democracy, Christian democracy, constitutional structure, and the welfare state. American Journal of Sociology, 99, 711-749.

Jæger, M. M. (2009). United but divided: welfare regimes and the level and variance in public support for redistribution. European Sociological Review, 25, 723-737.

Jakobsen, T. G. (2010). Public versus private: the conditional effect of state policy and institutional trust on mass opinion. European Sociological Review, 26, 307-318.

Kiewiet, D. R. (1984). Macroeconomics and Micropolitics: The Electoral Effects of Economic Issues. Chicago: University of Chicago Press.
Kinder, D. R. (1994). Reason and emotion in American political life. In Abelson, R. P. and Schank, R. C. (Eds.), Beliefs, Reasoning and Decision-making: Psycho-logic in Honor of Bob Abelson. Hillsdale, NJ: Erlbaum.

Korpi, W. (1983). The Democratic Class Struggle. London: Routledge.

Korpi, W. and Joakim, P. (2003). New Politics and Class Politics in the Context of Austerity and Globalization: Welfare State Regress in 18 Countries 1975-95. American Political Science Review, 97, 425-446.

Krosnick, J. A. (1990). Government policy and citizen passion: a study of issue publics in contemporary America. Political Behavior, 12, 59-92.

Kumlin, S. (2007a). Overloaded or undermined? European welfare states in the face of performance dissatisfaction. In Svallfors, S. (Ed.), The Political Sociology of the Welfare State. Stanford: Stanford University Press.

Kumlin, S. (2007b). The welfare state: values, policy preferences, and performance evaluations. In Dalton, R. J. and Klingemann, H. D. (Eds.), Oxford Handbook of Political Behavior. Oxford: Oxford University Press.

Larsen, C. A. and Andersen, J. (2009). How new economic ideas changed the Danish welfare state: the case of neoliberal ideas and highly organized social democratic interests. Governance, 22, 239-261.

Lewis-Beck, M. S. (1986). Comparative economic voting: Britain, France, Germany, Italy. American Journal of Political Science, 30, 315-346.

Lewis-Beck, M. S. (1988). Economics and the American voter: past, present, future. Political Behavior, 10, $5-21$.

Lewis-Beck, M. S. and Stegmaier, M. (2007). Economic models of voting. In Dalton, R. J. and Klingemann, H. D. (Eds.), Oxford Handbook of Political Behavior. Oxford: Oxford University Press.

Long, J. S. (1997). Regression Models for Categorical and Limited Dependent Variables. Thousand Oaks, CA: SAGE.

Nannestad, P. and Paldam, M. (1994). The VP-function: a survey of the literature on vote and popularity functions after 25 years. Public Choice, 79, 213-245.

Palier, B. (Ed.), (2010). A Long Goodbye to Bismarck?: The Politics of Welfare Reform in Continental Europe. Amsterdam: Amsterdam University Press.

Petersen, P. A. (1995). The welfare state: the security dimension. In Borre, O. and Scarborough, E. (Eds.), The Scope of Government. Oxford: Oxford University Press. 
Pierson, P. (Ed.), (2001). The New Politics of the Welfare State. Oxford: Oxford University Press.

Powell, G. B. and Whitten, G. D. (1993). A crossnational analysis of economic voting: taking account of the political context. American Journal of Political Science, 37, 391-414.

Schumacher, G. (2012). Marx'or the Market? Intra-party Power and Social Democratic Welfare State Retrenchment. West European Politics, 35 (5), 1024-1043.

Slothuus, R. (2007). Framing deservingness to win support for welfare state retrenchment. Scandinavian Political Studies, 30, 323-344.

Stephens, J. D. (1979). The Transition from Capitalism to Socialism. Urbana: University of Illinois Press. van Kersbergen, K. and Hemerijck, A. (2004). Christian democracy, social democracy and the continental 'welfare without work' syndrome. In Ellison, N., Bauld, L. and Powell, M. (Eds.), Social Policy Review. Bristol, England: Policy Press, pp. 167-168.

van Kersbergen, K. (1995). Social Capitalism: A Study of Christian Democracy and the Post-war Settlement of the Welfare State. London: Routledge.

Weaver, R. K. (1986). The politics of blame avoidance. Journal of Public Policy, 6, 371-398.

Zaller, J. (1992). The Nature and Origins of Mass Opinion. Cambridge: Cambridge University Press. 